\title{
Correspondence
}

https://doi.org/10.11646/phytotaxa.308.1.16

\section{Massonia gypsicola (Asparagaceae, Scilloideae), a new species from the Knersvlakte in South Africa}

\author{
MARIO MARTÍNEZ-AZORÍN ${ }^{1 *}$, MICHAEL PINTER ${ }^{2}$, MANUEL B. CRESPO ${ }^{1}$, MARÍA ÁNGELES ALONSO \\ VARGAS $^{1} \&$ WOLFGANG WETSCHNIG ${ }^{2}$ \\ ${ }^{I} d C A R N$ (Depto. de Ciencias Ambientales y Recursos Naturales) \& CIBIO (Instituto Universitario de la Biodiversidad), Universidad de \\ Alicante, P. O. Box 99,E-03080 Alicante,Spain; e-mail: mmartinez@ua.es \\ ${ }^{2}$ Institute of Plant Sciences, NAWI Graz, Karl-Franzens-University Graz, Holteigasse 6, A-8010, Graz, Austria. \\ *author for correspondence
}

Asparagaceae (subfamily Scilloideae, tribe Hyacintheae) is alternatively regarded as Hyacinthaceae subfam. Hyacinthoideae, an option of our choice. Additional information on generic circumscriptions in Hyacinthoideae can be found in MartínezAzorín et al. (2013, 2014a, 2014b), Pinter et al. (2013) and Wetschnig et al. (2014).

The genus Massonia Houttuyn (1780: 424) occurs in South Africa and in southwestern Namibia and it belongs to subfamily Hyacinthoideae, tribe Massonieae (Speta 1998a, 1998b, Wetschnig et al. 2002, Pfosser et al. 2003, Manning et al. 2004). Originally, this genus was described to include a single species, Massonia depressa Houttuyn (1780: 424). However, botanical exploration of South Africa in the nineteenth century led Baker (1897) to accept 33 species in the genus. Recent studies in Massonia reduced the number of accepted species to 6 (van der Merwe 2002, Manning \& Goldblatt 2003, Summerfield 2004), 8 (Jessop 1976), 12 (Müller-Doblies \& Müller-Doblies 1997), or 14 (Species-2000 2017).

Our studies on Massonia revealed that the taxonomy of the genus, as accepted in recent revisions, is not satisfactory and several species have been overlooked and misunderstood (Wetschnig et al. 2012, 2014, 2016, Martínez-Azorín et al. 2013, 2014a, 2014b, 2015a, 2015b, Pinter et al. 2013, 2015).

Within the framework of a taxonomic revision of Massonia, the study of natural populations, cultivated material as well as herbarium vouchers, revealed existence of some populations of Massonia growing on gypcrete outcrops in Knersvlakte (Western Cape Province) that represent a distinct undescribed species based on clear morphological characters, ecology, and biogeography. Therefore, a formal description for this species, named Massonia gypsicola, is presented below including data on morphology, habitat, biology and distribution.

\section{Materials and Methods}

Detailed morphological studies of Massonia were undertaken on natural populations, cultivated specimens and herbarium vouchers, following the terminology used for species of Hyacinthaceae in Martínez-Azorín et al. (2007, 2009). Herbarium specimens from the herbaria ABH, B, BLFU, BM, BOL, E, G, GZU, GRA, HAL, K, L, LINN, M, MO, NBG, NU, NY, P, PRE, S, TCD, UPS, WU, Z, ZSS and ZT (acronyms according to Thiers 2017) were studied. Authors of the cited taxa follow IPNI (2017). Orthography of geographical names and grid-number system follows Leistner \& Morris (1976). Morphological data given in Table 1 are obtained from living plants and herbarium vouchers (M. gypsicola: 18 specimens from 2 populations; M. pseudoechinata: 74 specimens from 11 populations; M. roggeveldensis: 56 specimens from 6 populations; M. bakeriana: 17 specimens from 7 populations; M. mimetica: 25 specimens from 5 populations). The WW numbers correspond to the accession numbers of the living plant collection cultivated at the Botanical Garden of the Institute of Plant Sciences of the University of Graz. 
TABLE 1. Comparison of main characters of Massonia gypsicola and related species. Morphological data are obtained from living plants from the wild and cultivated and also herbarium vouchers as detailed in the Material and Methods section.

\begin{tabular}{|c|c|c|c|c|c|}
\hline & M. gypsicola & M. pseudoechinata & M. roggeveldensis & M. bakeriana & M. mimetica \\
\hline Leaf blade size $(\mathrm{cm})$ & $2.5-9 \times 1.5-5$ & $3-12 \times 2.5-8$ & $2-5 \times 2-3.5$ & $4-10 \times 5-10$ & $3.5-10 \times 3-9$ \\
\hline $\begin{array}{l}\text { Leaf emergences } \\
\text { per } \mathrm{cm}^{2}\end{array}$ & $15-40$ & $1-60$ & absent & $11-42$ & $10-25$ \\
\hline Leaf emergences & $\begin{array}{l}\text { conical to } \\
\text { hemisphaerical, } 0.4- \\
0.8 \mathrm{~mm} \text { in diameter } \\
\text { with a trichome on } \\
\text { top } 0.1-0.8 \mathrm{~mm} \text { long }\end{array}$ & $\begin{array}{l}\text { cone-like, } 0.2-0.4 \\
\text { mm in diameter, } \\
\text { with a deflexed, } \\
\text { thickened, smooth } \\
\text { trichome on top, } \\
0.2-0.5 \mathrm{~mm} \text { long }\end{array}$ & absent & $\begin{array}{l}\text { symmetrical, cone- } \\
\text { like, dark green, } \\
\text { with a small apical } \\
\text { papilla }\end{array}$ & $\begin{array}{l}\text { slightly } \\
\text { asymmetrical, } \\
\text { conical, } 1-2 \mathrm{~mm} \\
\text { in diameter, with a } \\
\text { short obtuse conical } \\
\text { cell on top }\end{array}$ \\
\hline Leaf margin & $\begin{array}{l}\text { entire to minutely } \\
\text { denticulate }\end{array}$ & $\begin{array}{l}\text { denticulate to shortly } \\
\text { ciliate-fimbriate }\end{array}$ & $\begin{array}{l}\text { minutely papillose- } \\
\text { denticulate }\end{array}$ & $\begin{array}{l}\text { entire to minute } \\
\text { papillose }\end{array}$ & entire \\
\hline Number of flowers & $10-25$ & $9-90$ & $10-40$ & $15-20$ & $12-31$ \\
\hline $\begin{array}{l}\text { Free perigone } \\
\text { segments at anthesis }\end{array}$ & $\begin{array}{l}5-8 \times 1.5-2 \mathrm{~mm} \\
\text { white with a short } \\
\text { greenish central } \\
\text { band at the tip, } \\
\text { reflexed with a slight } \\
\text { sigmoid curve at the } \\
\text { base but not inrolled }\end{array}$ & $\begin{array}{l}6-10 \times 1.5-2 \mathrm{~mm} \text {, } \\
\text { pure white, with } \\
\text { a short greenish } \\
\text { central band at the } \\
\text { tip, strongly reflexed } \\
\text { and inrolled with } \\
\text { a distinct sigmoid } \\
\text { curve at the base }\end{array}$ & $\begin{array}{l}6-10 \times 1.5-2 \mathrm{~mm} \\
\text { pure white } \\
\text { sometimes with } \\
\text { a short greenish } \\
\text { central band at the } \\
\text { tip, strongly reflexed } \\
\text { with a sigmoid } \\
\text { curve at the base } \\
\text { at anthesis, but not } \\
\text { distinctly inrolled }\end{array}$ & $\begin{array}{l}6-8 \times 1.2-2 \mathrm{~mm} \\
\text { with a short greenish } \\
\text { central band at the } \\
\text { tip, strongly reflexed } \\
\text { with a slight curve at } \\
\text { the base }\end{array}$ & $\begin{array}{l}6-9 \times 1.5-2 \mathrm{~mm} \text {, } \\
\text { with a green central } \\
\text { band, strongly } \\
\text { reflexed, inrolled } \\
\text { with a distinct } \\
\text { sigmoid curve at the } \\
\text { base }\end{array}$ \\
\hline $\begin{array}{l}\text { Perigone-filaments } \\
\text { tube }\end{array}$ & $\begin{array}{l}6-7 \times 2-3 \mathrm{~mm} \\
\text { narrowly } \\
\text { cylindrical, not } \\
\text { widening at the } \\
\text { upper portion, with a } \\
\text { circular mouth with } \\
\text { no gibbosities }\end{array}$ & $\begin{array}{l}10-15 \times 2-3 \mathrm{~mm} \\
\text { narrowly cylindrical, } \\
\text { not widening at the } \\
\text { upper portion, with } \\
\text { a hexagonal mouth } \\
\text { showing strongly } \\
\text { convex sides, giving } \\
\text { the appearance of } \\
\text { having } 6 \text { gibbosities }\end{array}$ & $\begin{array}{l}14-19 \times \text { ca. } 2 \mathrm{~mm} \\
\text { narrowly cylindrical, } \\
\text { not widening at the } \\
\text { upper portion, with } \\
\text { an almost closed } \\
\text { mouth enveloping } \\
\text { the style }\end{array}$ & $\begin{array}{l}9-13 \times 2-4 \mathrm{~mm} \text {, } \\
\text { cylindrical below, } \\
\text { funnel-shaped } \\
\text { above, bearing a } \\
\text { wide open mouth } \\
\text { that shows the ovary } \\
\text { in apical view }\end{array}$ & $\begin{array}{l}6-15 \times 2.5-4 \mathrm{~mm} \text {, } \\
\text { cylindrical or } \\
\text { slightly widening at } \\
\text { the upper portion, } \\
\text { tinged with reddish } \\
\text { above } \\
\text { the segments } \\
\text { insertion, with } 6 \\
\text { gibbosities } \\
\text { at the mouth of the } \\
\text { tube }\end{array}$ \\
\hline $\begin{array}{l}\text { Free portion of } \\
\text { filaments length } \\
(\mathrm{mm})\end{array}$ & $10-15$ & $8-12$ & $8-12$ & $12-18$ & $6-13$ \\
\hline $\begin{array}{l}\text { Filaments-tube } \\
\text { length }(\mathrm{mm})\end{array}$ & ca. 0.5 & ca. 1 & ca. 0.5 & ca. 0.5 & $1-2$ \\
\hline Anther colour & pale yellow & pale blue & pale blue & violet-purple & $\begin{array}{l}\text { pale orange with a } \\
\text { red flush or rarely } \\
\text { purplish-bluish }\end{array}$ \\
\hline Pollen colour & yellow & blue & blue & yellow & yellow \\
\hline Ovary (mm) & $\begin{array}{l}3-4 \times 1.5-2 \\
\text { gradually tapering to } \\
\text { the style }\end{array}$ & $\begin{array}{l}4-6 \times 1.8-2.1 \\
\text { gradually tapering to } \\
\text { the style }\end{array}$ & $\begin{array}{l}4-6 \times 1.8-2.1 \\
\text { gradually tapering to } \\
\text { the style }\end{array}$ & $\begin{array}{l}5-6 \times 1.7-2 \text {, slightly } \\
\text { contracted at } \\
\text { the joint with the } \\
\text { style }\end{array}$ & $\begin{array}{l}3-4.5 \times 2-2.5, \\
\text { gradually tapering to } \\
\text { the style }\end{array}$ \\
\hline Style length (mm) & $10-14$ & $15-17$ & $18-22$ & $16-20$ & $11-20$ \\
\hline Capsule (mm) & $7-12 \times 3-7$ & $10-17 \times 4-9$ & not studied & $10-12 \times 7-10$ & $6-14 \times 4-8$ \\
\hline Seed $(\mathrm{mm})$ & $1.6-2.0 \times 1.5-1.8$ & $1.5-2.1 \times 1.3-2$ & not studied & $1.4-1.6 \times 1.3-1.6$ & $1.5-1.8 \times 1.3-1.6$ \\
\hline Distribution & Knersvlakte & Bokkeveld & Roggeveld & $\begin{array}{l}\text { Kamiesberg, } \\
\text { Bokkeveld, Jan } \\
\text { Swartsberge and } \\
\text { Slangberge }\end{array}$ & $\begin{array}{l}\text { Surroundings of } \\
\text { Platbakkies, Loxton } \\
\text { and Victoria West }\end{array}$ \\
\hline
\end{tabular}




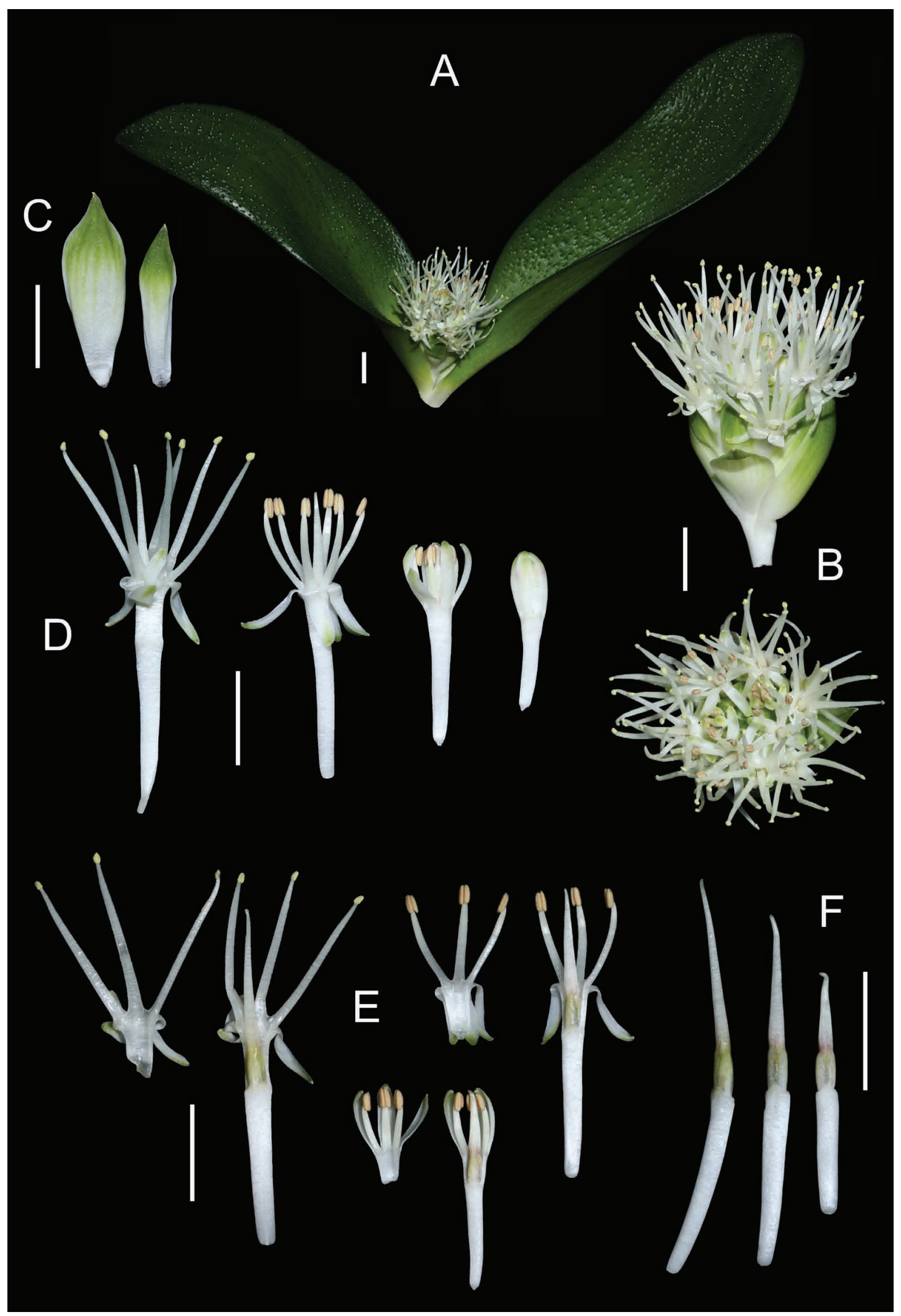

FIGURE 1. Massonia gypsicola Mart.-Azorín et al. in cultivation from the type locality in Knersvlakte, Western Cape province of South Africa (corresponding to the holotype MMA1298 pressed on 14/11/2016). A. Plant in flower, lateral view; B. Inflorescence, lateral and apical views; C. Bracts; D. Flowers from bud to full anthesis, lateral views; E. Dissected flowers, lateral views; F. Gynoecia from bud to full anthesis, lateral views. Scale bars $1 \mathrm{~cm}$. 


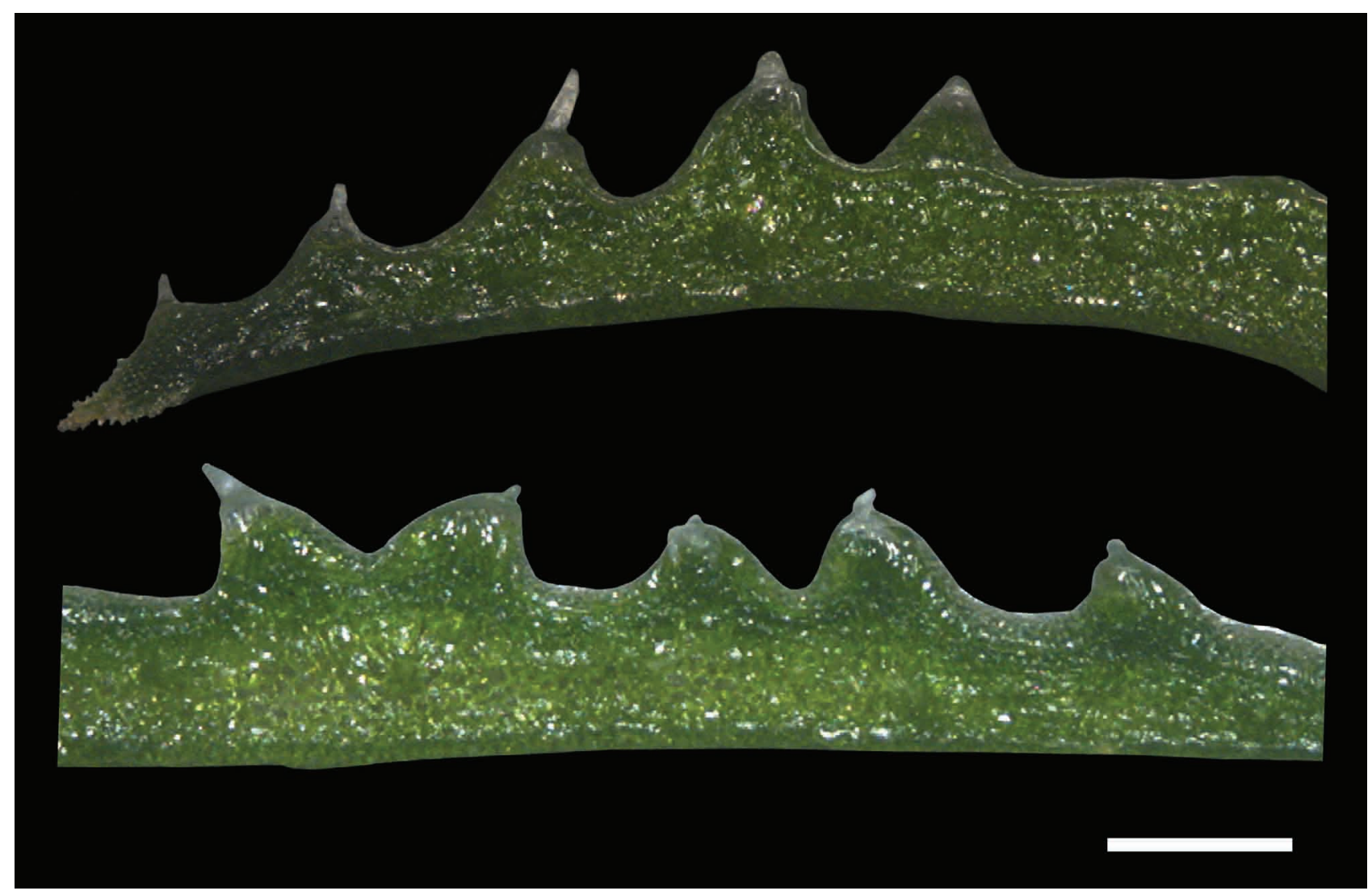

FIGURE 2. Leaf emergences of Massonia gypsicola Mart.-Azorín et al. Light microscope images. Scale bar: $1 \mathrm{~mm}$.

\section{Description of the new species}

Massonia gypsicola Mart.-Azorín, M.Pinter, M.B.Crespo, M.A.Alonso \& Wetschnig, sp. nov. (Figs. 1, 2)

Species notabilis combinatione propria characterum ab ceteris speciebus Massoniae bene distincta. Folia pustulata pustulis leviter asymmetricis conicis vel hemisphaericis 0.4-0.8 mm diametro plus minusve numerosis (15-40) obsita, quae ad apicem papilla late vel anguste conica et valida $0.1-0.8$ mm long. munitas. Flores albidis, ad apicem segmentorum fascia longitudinali viridi instructis; tubo brevi (ad $7 \mathrm{~mm}$ long.) et strictissimo, ad faucem egibboso, longitudine ovarium valde occultante; et segmentis perigonii 5-8 $\times 1.5-2 \mathrm{~mm}$, reflexis sed non revolutis, a basi vix sigmoideo-curvatis. Antherae statu clauso ca. $2 \times 1 \mathrm{~mm}$, luteolae; polline luteo subconcoloro. Ovarium conicum vel suboblongum, ca. 3-4 × 1.5-2 mm, in stylo gradualiter desinente. Semina 1.6-2.0 × 1.5-1.8 $\mathrm{mm}$, globosa, nigra, laevia.

Type:-SOUTH AFRICA. Western Cape. Vanrhynsdorp (3118): Knersvlakte, ca. $4 \mathrm{~km} \mathrm{SW}$ of N7 on the gravel road parallel to the railway, farm Quaggas Kop 215 (-BC), crevices and shallow soil on gypcrete outcrops, $135 \mathrm{~m}$ elevation, 14 November 2016 ex hort. in Graz (Austria), M. Martinez-Azorin, M. Pinter, M.B. Crespo \& M.A. Alonso MMA1298 (holotype GRA!; isotypes ABH!, GZU!).

Deciduous geophyte. Bulb ovoid to subglobose, 1.4-4.3 × 0.9-4 cm, hypogeal, with white, fleshy bulb scales covered by pale brown, papery or slightly leathery outer tunics. Leaves 2, synanthous, opposite, appressed to the ground, ovoid, with an acute apex and a short apicule about 2-3 mm long, limb $2.5-9 \times 1.5-5 \mathrm{~cm}$ (up to $15 \mathrm{~cm}$ long in cultivation), with narrow, membranous, entire to minutely denticulate margins; adaxial side green, with 15-40 slightly asymmetrical, conical to hemisphaerical, emergences per $\mathrm{cm}^{2}$, which are $0.4-0.8 \mathrm{~mm}$ in diameter, with a conical to elongated and slightly deflexed, thickened, smooth trichome on top, 0.1-0.8 mm long; abaxial side smooth, green; petiole $0.5-2.5 \mathrm{~cm}$ long. Inflorescence a dense, subcapitate raceme, up to 2-3 cm long, with 10-25 flowers, shortly overtopping ground level. Bracts narrowly obovate, attenuate at the apex, 15-25 $\times 5-9 \mathrm{~mm}$, green in the upper half with white membranous margins and base, glabrous, entire. Pedicels at anthesis $8-16 \mathrm{~mm}$ long. Flowers pentacyclic, trimerous. Perigone pure white; tepals 6, free segments 5-8 $\times 1.5-2 \mathrm{~mm}$, entire, with a short greenish central band at the tip, straight and erect in bud, reflexed with a sigmoid curve at the base but not distinctly inrolled at anthesis; perigone-filaments tube 6-7 $\times 2-3 \mathrm{~mm}$, narrowly cylindrical, not widening in the upper portion, with a circular mouth with no gibbosities, the ovary included in the tube and not visible. Stamens 6 , filaments long-attenuate, spreading at anthesis, slightly arcuate, white, $10-15 \mathrm{~mm}$ long, shortly connate at the base for ca. 0.5 
$\mathrm{mm}$ above the perigone segments; anthers oblong, pale yellow, ca. $2 \times 1 \mathrm{~mm}$ when closed, dorsifixed, with yellow pollen. Gynoecium obclavate, compound, tricarpellar, with axile placentation. Ovary superior, conical to suboblong, white to pale green with a purple tinge, 3-4 × 1.5-2 mm, gradually tapering to the style, with $12-14$ ovules per locule. Style white, erect, 10-14 $\mathrm{mm}$ long at anthesis, narrowly conical, gradually tapering from the ovary to the acute, simple stigma. Capsule ovate in lateral view, trigonous with blunt edges in apical view, 7-12 × 3-7 mm. Seeds globose, black, 1.6-2.0 × 1.5-1.8 mm, smooth.

Etymology:- The specific epithet (gypsicola: growing in gypsum substrate) refers to the distinct and unique habitat of this new species; this is so far the only taxon in Massonia occurring on gypcrete outcrops.

Phenology:-Massonia gypsicola flowers between May and July in the wild and fruits appear from July to August. In cultivation in Graz (Austria) it flowers around November and fruits appear in late December.

Habitat:-Massonia gypsicola occurs in crevices and shallow soil on eroding outcrops of gypcrete (deep weathering gypsum rich duripans; see also Francis 2008), rich in calcium sulphate, from 100 to $150 \mathrm{~m}$ of elevation. The surrounding vegetation is classified as Knersvlakte Quartz Vygieveld (SKk3) and Central Knersvlakte Vygieveld (SKk2). The region is characterised by winter rainfall peaking from May to August, and dry hot summers, with a mean annual precipitation of 110 $\mathrm{mm}$ and rare occurrence of frost (Mucina \& Rutherford 2006). Knersvlakte is a worldwide well known area for succulents including many endemic taxa, and this new Massonia species increases the value of this region.

Distribution:- The new species is known to us only from two localities west of N7 in Knersvlakte, and appears to be endemic to this area (Fig. 3). Further populations are expected to be found on similar habitats close-by.

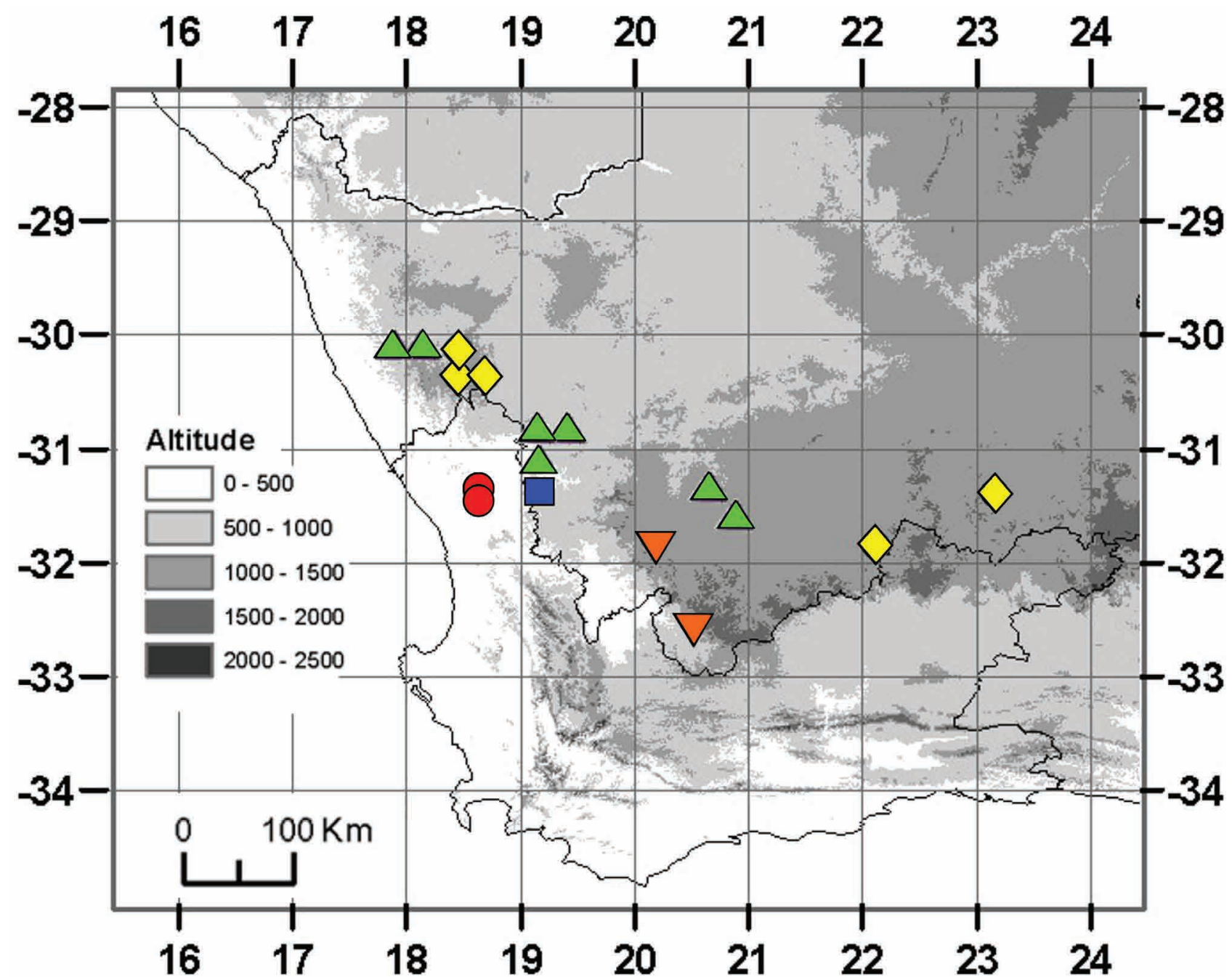

FIGURE 3. Known distribution of Massonia gypsicola Mart.-Azorín et al. in Knersvlakte in South Africa and related species (red circle: M. gypsicola; blue square: M. pseudoechinata Mart.-Azorín et al.; green triangle: M. bakeriana M.Pinter et al.; yellow diamond: M. mimetica Mart.-Azorín et al., orange triangle: M. roggeveldensis Mart.-Azorín et al.). 
Taxonomic relationships:-Massonia gypsicola can be easily distinguished by the leaves covered by distinct conical to hemisphaerical emergences that usually bear a distinct trichome on top; white flowers with short and narrow perigonefilaments tube; yellow anthers and pollen; and obclavate gynoecium (Table 1). Its morphologically closest relative appears to be Massonia pseudoechinata Mart.-Azorín, M.Pinter \& Wetschnig in Martínez-Azorín et al. (2015b: 124), but the latter differs by leaves with scarce to numerous small emergences; flowers with much longer perigone-filaments tube; strongly reflexed and inrolled perigone segments; shorter filaments, the blue anthers and pollen; longer ovary and style; and bigger capsules (Table 1; Martínez-Azorín et al. 2015b). Massonia pseudoechinata grows on top of the Bokkeveld Plateau near Nieuwoudtville and the Vanrhyns Pass, at elevations of about 700-800 m a.s.1. and vegetation classified as Bokkeveld Sandstone Fynbos and Nieuwoudtville Shale Renosterveld (Mucina \& Rutherford 2006). The general flower morphology of M. gypsicola, especially the obclavate gynoecium, links this species to M. pseudoechinata, M. roggeveldensis Mart.-Azorín, M.Pinter \& Wetschnig in Martínez-Azorín et al. (2015b: 122), M. bakeriana M.Pinter, Mart.-Azorín \& Wetschnig in Pinter et al. (2015: 52), M. mimetica Mart.-Azorín, M.Pinter, M.B.Crespo \& Wetschnig in Martínez-Azorín et al. (2013: 191), M. jasminiflora Burch. ex Baker (1870: 390) and related species (Table 1; Martínez-Azorín et al. 2013, 2014b, 2015b, Pinter et al. 2015). However, none of the related species shows the distinct combination of character-states occurring in Massonia gypsicola (Table 1).

Additional material studied (paratypes):-SOUTH AFRICA. Western Cape. Vanrhynsdorp (3118): Knersvlakte, ca. $8 \mathrm{~km} \mathrm{~W}$ of $\mathrm{N} 7$ from the railway crossing, farm Wolvenest 212 (-BC), gypcrete outcrop south of the gypsum mine, $125 \mathrm{~m}$ elevation, 6 June 2015 in flower, A. Le Roux (photo!); Vanrhynsdorp (3118): Knersvlakte, ca. 4 km SW of N7 on the gravel road parallel to the railway, farm Quaggas Kop 215 (-BC), 125 m elevation, 7 July 2015 in fruit and in bud, N. Helme (iSpot photo!, https://www.ispotnature.org/node/697552); a photograph of M. gypsicola from the Knersvlakte in flower (as "Kners Massonia echinata") mounted on a herbarium sheet together with a photograph identified as Brunsvigia radulosa (NBG!).

\section{Acknowledgements}

This work was partly supported by Fundación Ramón Areces (Spain), and H2020 Research and Innovation Staff Exchange Programme of the European Commission, project 645636: 'Insect-plant relationships: insights into biodiversity and new applications' (FlyHigh). We are grateful to the managers and rangers of the Knersvlakte Nature reserve for allowing us to enter and collect plant samples and for accompanying us in the field. We thank the owners of farm Quaggas Kop for allowance to collect samples at the type locality. Annelise Le Roux kindly provided photographs and information on a locality of the new species. Ladislav Mucina provided interesting comments on the ecology of the new species that improved the manuscript. CapeNature of Western Cape Province provided permission to collect herbarium specimens (collecting permits numbers AAA008-00031-0028 and 0028-AAA008-00203). We acknowledge the help of all herbaria curators who kindly provided material and information. We also would like to thank all the numerous garden and plant enthusiasts who publish valuable information and images on plants on the internet and who contribute substantially to the increase of knowledge.

\section{References}

Baker, J.G. (1870) A revision of the genera and species of herbaceous capsular gamophyllous Liliaceae. Journal of the Linnean Society. Botany 11: 349-436.

https://doi.org/10.1111/j.1095-8339.1870.tb00068.x

Baker, J.G. (1897) Liliaceae. In: Thiselton-Dyer, W.T. (Ed.) Flora Capensis 6. Reeve and Co., London, pp. $253-525$.

Francis, M.L. (2008) Soil Formation on the Namaqualand Coastal Plain. Ph.D. Thesis, University of Stellenbosch, Stellenbosch, South Africa, $246 \mathrm{pp}$.

Houttuyn, M. (1780) Natuurlijke Historie of uitvoerige Beschryving der Dieren, Planten en Mineraalen, volgens het Samenstel van der Heer Linnaeus II, 12. Erven van F. Houttuyn, Amsterdam, 558 pp.

IPNI. (2017) The International Plant Names Index. Available from: http://www.ipni.org (accessed February 2017)

Jessop, J.P. (1976) Studies in the bulbous Liliaceae in South Africa 6. The taxonomy of Massonia and allied genera. Journal of South African Botany 42: 401-437.

Leistner, O.A. \& Morris, J.W. (1976) Southern African place names. Annals of the Cape Provincial Museum 12: 1-565.

Manning, J.C. \& Goldblatt, P. (2003) Hyacinthaceae. In: Germishuizen, G. \& Meyer, N.L. (Eds.) Plants of Southern Africa: An annotated checklist [4th approach to the List of Species of Southern African Plants]. Strelitzia 14: 1054-1071. [National Botanical Institute Pretoria]

Manning, J.C., Goldblatt, P. \& Fay, M.F. (2004) A revised generic synopsis of Hyacinthaceae in Sub-Saharan Africa, based on molecular evidence, including new combinations and the new tribe Pseudoprospereae. Edinburgh Journal of Botany 60: 533-568. 
Martínez-Azorín, M., Crespo, M.B. \& Juan, A. (2007) Taxonomic revision of Ornithogalum subg. Cathissa (Salisb.) Baker (Hyacinthaceae). Anales del Jardin Botánico de Madrid 64: 7-25.

http://doi.org/10.3989/ajbm.2007.v64.i1.47

Martínez-Azorín, M., Crespo, M.B. \& Juan, A. (2009) Taxonomic revision of Ornithogalum subg. Beryllis (Hyacinthaceae) in the Iberian Peninsula and the Balearic Islands. Belgian Journal of Botany 142: 140-162.

Martínez-Azorín, M., Pinter, M., Crespo, M.B., Pfosser, M. \& Wetschnig, W. (2013) Massonia mimetica (Hyacinthaceae, Hyacinthoideae), a new remarkable species from South Africa. Stapfia 99: 187-197.

Martínez-Azorín, M., Clark, V.R., Pinter, M., Dold, A.P., Crespo, M.B., Barker, N.P., Pfosser, M. \& Wetschnig, W. (2014a) Massonia dentata (Asparagaceae, Scilloideae), a new species from the Nuweveldberge, southern Great Escarpment, South Africa and typification of M. calvata. Phytotaxa 175: 201-215. http://doi.org/10.11646/phytotaxa.175.4.2

Martínez-Azorín, M., Pinter, M., Deutsch, G., Brudermann, A., Dold, A.P., Crespo, M.B., Pfosser, M. \& Wetschnig, W. (2014b) Massonia amoena (Asparagaceae, Scilloideae), a striking new species from the Eastern Cape, South Africa. Phytotaxa 181: 121-137. http://doi.org/10.11646/phytotaxa.181.3.1

Martínez-Azorín, M., Dold, A.P., Pinter, M., Slade, J., Crespo, M.B., Milkuhn, G. \& Wetschnig, W. (2015a) Massonia obermeyerae (Asparagaceae, Scilloideae), a new species from South Africa. Phytotaxa 205: 39-50. http://doi.org/10.11646/phytotaxa.205.1.3

Martínez-Azorín, M., Pinter, M., Crespo, M.B., Slade, J., Deutsch, G. \& Wetschnig, W. (2015b) Clarification of Massonia echinata and some other frequently misunderstood Massonia species (Asparagaceae, Scilloideae), with the description of M. pseudoechinata and M. roggeveldensis. Phytotaxa 239: 101-129. http://doi.org/10.11646/phytotaxa.239.2.1

Mucina, L. \& Rutherford, M.C. (Eds.) (2006) The Vegetation of South Africa, Lesotho and Swaziland. Strelitzia 19. South African National Biodiversity Institute, Pretoria, $807 \mathrm{pp}$.

Müller-Doblies, U. \& Müller-Doblies, D. (1997) A partial revision of the tribe Massonieae (Hyacinthaceae). Feddes Repertorium 108: 49-96.

http://doi.org/10.1002/fedr.19971080106

Pfosser, M., Wetschnig, W., Ungar, S. \& Prenner, G. (2003) Phylogenetic relationships among genera of Massonieae (Hyacinthaceae) inferred from plastid DNA and seed morphology. Journal of Plant Research 116: 115-132.

Pinter, M., Brudermann, A., Crespo, M.B., Deutsch, G., Martínez-Azorín, M., Müller-Doblies, U., Müller-Doblies, D., Pfosser, M. \& Wetschnig, W. (2013) Massonia citrina (Hyacinthaceae, Hyacinthoideae) - a new species from the Western Cape Province (South Africa). Phytotaxa 112: 50-56.

http://doi.org/10.11646/phytotaxa.112.2.3

Pinter, M., Martínez-Azorín, M., Crespo, M.B. \& Wetschnig, W. (2015) Massonia bakeriana (Asparagaceae, Scilloideae), a new pustulate species from the Northern Cape Province (South Africa). Phytotaxa 222: 51-60.

http://doi.org/10.11646/phytotaxa.222.1.5

Species-2000 (2017) Annual Checklist. Available from: http://www.sp2000.org/ (accessed February 2017)

Speta, F. (1998a) Hyacinthaceae. In: Kubitzki, K. (Ed.) The families and genera of vascular plants 3. Springer, Berlin, pp. 261-285. https://doi.org/10.1007/978-3-662-03533-7_35

Speta, F. (1998b) Systematische Analyse der Gattung Scilla L. s.l. (Hyacinthaceae). Phyton (Horn) 38: 1-141.

Summerfield, A. (2004) A synopsis of the biosystematic study of the seven minor genera of the Hyacinthaceae. Bulbs Bulletin of the International Bulb Society 6: 24-36.

Thiers, B. (2017) Index Herbariorum: A global directory of public herbaria and associated staff. New York Botanical Garden's Virtual Herbarium. Available from: http://sweetgum.nybg.org/ih/ (accessed February 2017)

Van der Merwe, A. (2002) A biosystematic study of the seven minor genera of the Hyacinthaceae. Ph.D. Thesis, University of Stellenbosch, Stellenbosch, South Africa.

Wetschnig, W., Pfosser, M. \& Prenner, G. (2002) Zur Samenmorphologie der Massonieae Baker 1871 (Hyacinthaceae) im Lichte phylogenetisch interpretierter molekularer Befunde. Stapfia 80: 349-379.

Wetschnig, W., Brudermann, A., Knirsch, W., Pinter, M. \& Pfosser, M. (2012) Massonia pustulata Jacq. 1791 and M. longipes Baker 1897 (Hyacinthaceae), two frequently misunderstood species-or how M. pustulata became depressed. Stapfia 97: $210-221$.

Wetschnig, W., Martínez-Azorín, M., Pinter, M., Brudermann, A., Deutsch, G., Crespo, M.B., Dold, A.P. \& Pfosser, M. (2014) Massonia saniensis (Asparagaceae, Scilloideae), a new species from Lesotho. Phytotaxa 173: 181-195.

http://doi.org/10.11646/phytotaxa.173.3.1

Wetschnig, W., Martínez-Azorín, M. \& Pinter, M. (2016) Massonia thunbergiana (Hyacinthaceae-Hyacinthoideae), a new species from the cold heart of South Africa. Phyton (Horn) 56: 111-119. 